\title{
What Should Be the Prostate Specific Antigen Threshold for Prostate Biopsy?
}

\section{Prostat Biyopsisinde Prostat Spesifik Antijen Eşik Değeri Ne Olmalıdır?}

\author{
Hasan Deliktaş, Hayrettin Şahin \\ Muğla Sıtkı Kocman University Faculty of Medicine, Department of Urology, Muğla, Turkey
}

\section{Abstract}

\begin{abstract}
Aim: There is still uncertainty today regarding the prostate specific antigen (PSA) threshold for prostate biopsy. From this point of view, we aimed to investigate the PSA threshold for prostate biopsy in this study.

Methods: We retrospectively evaluated medical records of 375 patients, who underwent 12-16-core transrectal ultrasound-guided prostate biopsy between September 2012 and November 2015. The patients were divided into three groups according to the PSA values: group 1: $2.5-4 \mathrm{ng} / \mathrm{mL}$, group 2: $4.1-10 \mathrm{ng} / \mathrm{mL}$ and group 3: $>10 \mathrm{ng} /$ $\mathrm{mL}$. Age, prostate volume, prostate cancer detection rate, Gleason score, the average core length and the core length obtained per cc of prostate volume were compared between the groups.
\end{abstract}

Results: The mean age of the patients was $64.39 \pm 7.62$ years and the mean cancer detection rate was $26.7 \%$, namely $11.5 \%$ (3/26), $17.4 \%$ $(43 / 247)$ and $52.9 \%(54 / 102)$ in the groups 1,2 and 3, respectively. Prostate cancer was not detected in any patient with a PSA value of $<3.6 \mathrm{ng} / \mathrm{mL}(\mathrm{n}=13)$.

Conclusion: Since prostate cancer was not detected in any patient with a PSA value of $<3.6 \mathrm{ng} / \mathrm{mL}$ in our study, we suggest higher PSA threshold values in order to reduce unnecessary prostate biopsy procedures.

Keywords: Prostate cancer, prostate specific antigen threshold, prostate biopsy
Öz

Amaç: Prostat biyopsisi için prostat spesifik antijen (PSA) eşik değerinin ne olması gerektiği konusunda belirsizlikler devam etmektedir. Çalışmamızda prostat biyopsisi için PSA eşik değerini belirlemeyi amaçladık.

Yöntemler: Eylül 2012 - Kasım 2015 tarihleri arasında transrektal ultrason kılavuzluğunda 12-16 kor prostat biyopsisi yapılan 375 hastanın kayıtları retrospektif olarak analiz edildi. Hastalar PSA değerine göre üç gruba ayrıldı. Grup 1; 2,5-4 ng/mL, grup 2; 4,1-10 ng/mL ve grup 3; >10 ng/mL. Gruplarda; prostat volümleri, yaş, prostat kanser saptama oranları, gleason skorları, ortalama kor uzunlukları ve prostat cc'si başına alınan kor uzunlukları karşılaştıııldı.

Bulgular: Kanser saptama oranı \%26,7 idi. Hastaların yaş ortalaması $64,39 \pm 7,62$ yıl idi. Gruplarda kanser saptama oranları sırasıyla $\% 11,5$ (3/26), \%17,4 (43/247) ve \% 52,9 (54/102) idi. PSA değeri 3,6 ng/ mL'den küçük olan hiçbir hastada $(n=13)$ prostat kanseri saptanmadı.

Sonuç: Çalışmamızda PSA $<3,6 \mathrm{ng} / \mathrm{mL}$ olan hiçbir hastada prostat kanseri saptanmadı. PSA eşik değerinin daha yukarı çekilmesi gereksiz prostat biyopsilerini azaltabilir.

Anahtar Sözcükler: Prostat kanseri, prostat spesifik antijen eşik değeri, prostat biyopsisi

Detection rates for prostate cancer showed an increase with the use of serum PSA for screening purposes. Widespread use of PSA screening has led to an increase of $70-80 \%$ in prostate biopsy procedures while reducing rates of mortality due to prostate cancer (2). The PSA threshold for prostate biopsy was determined as $4 \mathrm{ng} / \mathrm{ml}$ by Catalona et al. (3). However, it was proposed later to be $2.5 \mathrm{ng} / \mathrm{mL}$ because cancer was detected in $22 \%$ of patients having a PSA level of $2.5-4 \mathrm{ng} / \mathrm{mL}$ in subsequent 
studies $(4,5)$. There are still uncertainties today regarding the PSA threshold for prostate biopsy.

Although lowering the PSA threshold will result in an increase in the detection rate of prostate cancer, it will also cause an increase in the number of patients diagnosed with clinically insignificant prostate cancer and eventually unnecessary treatment in these patients.

In our study, we aimed to evaluate the differences between the groups of patients who underwent TRUSguided prostate biopsy and displayed different PSA values, by comparing prostate cancer detection rates, the average core lengths, the core lengths obtained per cc of prostate volume and the Gleason scores.

\section{Methods}

Medical records of 375 patients who had indication for biopsy and subsequently underwent TRUS-guided prostate biopsy between September 2012 and November 2015 in our clinic were retrospectively analyzed. Patients with initial biopsy were included in the study. Those with second biopsy were excluded from the study. The patients were divided into three groups according to their PSA values: group-1: $2.5-4 \mathrm{ng} / \mathrm{mL}$, group-2: $4.1-10 \mathrm{ng} / \mathrm{mL}$ and group-3: $>10 \mathrm{ng} / \mathrm{mL}$. The parameters that we compared between the groups were prostate cancer detection rates, Gleason score, average core lengths and the core length obtained per cc of prostate volume (6), which were used for the first time in our study. The study was approved by the Muğla Sıtkı Koçman University Scientific Research and Publication Ethics Committee (Approval number: 5061).

\section{Biopsy Technique}

Biopsy was performed with the patient in the lateral decubitus position with implementing either periprostatic nerve blockade or sedation procedure using midazolam and remifentanil (7). An 18-gauge biopsy needle was used for the biopsy. Using the sextant biopsy technique, 1216 core biopsies were taken depending on the prostate volume from the peripheral zone. In our previous study, we identified that cancer detection rates increased when the number of core taken was increased depending on prostate volume. Therefore, we performed 12-16 core biopsies depending on prostate volume (6). Each biopsy core was taken into specimen tubes containing formaldehyde and separately labeled to identify the location and sent for pathological assessment.

Total core length and prostate volume was calculated for each patient. The average core length was calculated by dividing the total core length into the number of cores. The core length obtained per prostate volume (cc) was determined by dividing the total core length into the prostate volume for each patient. Each core was measured in millimeters in macroscopic evaluation. For the patients diagnosed with cancer in pathological evaluation, the percentage of cancer and Gleason score was determined for each core. The cases with a PSA level of $<10 \mathrm{ng} / \mathrm{mL}$, a Gleason score of $\leq 6$, the number of positive cores $\leq 2$ and involvement in each core $\leq 50 \%$ were considered clinically insignificant prostate cancer (8).

SPSS 20.0 for Windows (SPSS Inc, Chicago, IL, USA) program was used for the statistical analysis of the data. The data was analyzed using the one-way ANOVA and independent t-test. A p value of less than 0.05 was considered statistically significant.

\section{Results}

Cancer detection rate was $26.7 \%$ (100/375). The mean age of the patients was $64.39 \pm 7.62$ years, the mean PSA level was $15.69 \pm 40.94 \mathrm{ng} / \mathrm{mL}$, and the mean prostate volume was $53.97 \pm 23.70 \mathrm{cc}$.

Cancer detection rate was $11.5 \%(3 / 26), 17.4 \%$ $(43 / 247)$ and $52.9 \%$ (54/102) in Groups 1, 2 and 3 , respectively. Three patients of Group 1 who were diagnosed with cancer had a Gleason score of $3+3=6$ and all were having clinically insignificant prostate cancer. There was no statistical difference between the groups in terms of average core length and the core length obtained per cc of prostate volume. The rate of cancer detection showed an increase with increasing age and PSA values and a decrease with increasing prostate volumes $(p<0.001$ for all values). For the groups 1 and 2 and 3, average Gleason scores were 6, 6.39 and 7.20 , respectively. PSA values were found to be $3.6,3.9$ and $4.0 \mathrm{ng} / \mathrm{mL}$ in three patients of Group 1 who were diagnosed with prostate cancer. Prostate cancer was not detected in any of the patients $(\mathrm{n}=13$ ) having a PSA value of $<3.6 \mathrm{ng} / \mathrm{mL}$ (Table 1, 2).

The Gleason scores were not affected by age, prostate volume, average core lengths and the core length obtained per $\mathrm{cc}$ of the prostate volume whereas they increased as PSA values increased $(p=0.004)$ (Table 3).

\section{Discussion}

Digital rectal examination, blood PSA level and prostate biopsy are widely used in the diagnosis of prostate cancer. We observed that the number of patients diagnosed with prostate cancer increased along with the use of PSA as a screening test for prostate cancer. Consequently, mortality rates due to prostate cancer decreased; on the other hand, there are also claims such that some patients are given unnecessary treatments. As it is known, PSA is a serum marker with higher specificity for organ but lower specificity for cancer. Hence, PSA is not exactly the required marker but yet the most commonly used screening method today for the diagnosis of prostate cancer. Abnormal 
digital rectal examination findings and/or high levels of PSA constitute prostate biopsy indications. There is still debate today, about what the PSA threshold value should be for prostate biopsy indication $(9,10)$.

In a study by Catalona et al. (3) in 1991, PSA cutoff value of $4 \mathrm{ng} / \mathrm{mL}$ was suggested to be used with an acceptable sensitivity for prostate biopsy (3). In their subsequent study, the same group demonstrated that the number of proposed prostate biopsy increased from $8 \%$ to $17 \%$ by decreasing the PSA threshold from $4 \mathrm{ng} / \mathrm{mL}$ to $2.6 \mathrm{ng} / \mathrm{mL}$ and prostate cancer could be detected at a rate of $22 \%$ within this interval (5).

Thompson et al. (11) detected prostate cancer among $10.1 \%$ and $17 \%$ of patients with PSA levels of $\leq 1 \mathrm{ng} / \mathrm{ml}$ and $1.1-2 \mathrm{ng} / \mathrm{mL}$, respectively. In another study, extracapsular spread was detected in $30 \%$ of the cancer cases with a PSA level of 4.1-10 ng/mL and worse prognosis was shown in these cases when compared with organ-confined cancer cases (12). In our country,
Albayrak et al. (13) reported cancer detection rates of $25 \%, 17.1 \%$ and $51.2 \%$ in patients with PSA levels of 2.5-4, 4.1-10 and $>10 \mathrm{ng} / \mathrm{mL}$, respectively. In our study, cancer detection rate was found to be $11.5 \%, 17.4 \%$ and $52.9 \%$ in patients having PSA levels of 2.5-4, 4.1-10 and $>10 \mathrm{ng} / \mathrm{mL}$, respectively. Comparison of our results with those reported by Albayrak et al. (13) revealed close similarity for group 2 and 3 patients whereas we detected cancer at a lower level for group 1 patients. Given the increased cancer detection rates at higher PSA levels, we may conclude that our results were more consistent.

Esen and Avunduk (14) compared PSA levels and Gleason scores and found PSA levels of 13, 24, 90 and $113 \mathrm{ng} / \mathrm{dL}$ in patients grouped as GS 2-4, GS 5-6, GS 7 and GS 8-10, respectively. We determined Gleason scores of 6, 6.3 and 7.2 in patients grouped according to the PSA levels as $2.5-4,4,1-10$ and $>10 \mathrm{ng} / \mathrm{mL}$.

Despite such high prevalence of prostate cancer, lifetime risk of developing clinical prostate cancer is

\begin{tabular}{|c|c|c|c|c|}
\hline & $\begin{array}{l}P S A=2.5-4 \mathrm{ng} / \mathrm{mL} \\
(\mathrm{n}=26)\end{array}$ & $\begin{array}{l}P S A=4.1-10 \mathrm{ng} / \mathrm{mL} \\
(\mathrm{n}=247)\end{array}$ & $P S A>10 \mathrm{ng} / \mathrm{mL}(\mathrm{n}=102)$ & $\mathrm{p}$ value \\
\hline Age (years) & $63(49-74)$ & $64(43-77)$ & $69(48-81)$ & $<0.001$ \\
\hline Prostate volume (cc) & $40(22-118)$ & $50(17-170)$ & $54(20-211)$ & $<0.001$ \\
\hline The mean core length $(\mathrm{mm})$ & $10.6(5.6-17.4)$ & $11.0(4.5-19.3)$ & $11.0(6.6-18.5)$ & 0.79 \\
\hline The mean core length taken per $\mathrm{cc}$ of prostate $(\mathrm{cc} / \mathrm{mm})$ & $2.8(1.1-8.0)$ & $2.4(0.4-7.6)$ & $2.9(0.5-7.6)$ & 0.053 \\
\hline The mean Gleason grade & 6 & $6,39(6-10)$ & $7.2(6-10)$ & $<0.001$ \\
\hline PSA (ng/mL) & $3.5(2.4-3.9)$ & $5.8(4.0-10.0)$ & $17(10.1-591)$ & $<0.001$ \\
\hline Dedection of prostate cancer $n(\%)$ & $3 / 26(11.5 \%)$ & $43 / 247(17.4 \%)$ & $54 / 102(52.9 \%)$ & $<0.001$ \\
\hline
\end{tabular}

\begin{tabular}{|l|l|l|l|}
\hline Table 2. Characteristics of the patients & Cancer $(\mathbf{n = 1 0 0})$ & No cancer $(\mathbf{n = 2 7 5 )}$ & $\mathbf{p ~ v a l u e ~}$ \\
\hline & $69(49-81)$ & $63(43-77)$ & $<0.001$ \\
\hline Age (years) & $43(18-115)$ & $53(17-211)$ & $<0.001$ \\
\hline Prostate volume (cc) & $3.1(0.9-7.6)$ & $2.5(0.4-8.0)$ & $<0.001$ \\
\hline The mean core length taken per cc of prostate $(\mathrm{cc} / \mathrm{mm})$ & $11.3(3.6-591)$ & $5.9(2.4-44.8)$ & $<0.001$ \\
\hline PSA $(\mathrm{ng} / \mathrm{mL})$ & $10.8(4.5-18.4)$ & $11.0(5.1-19.3)$ & 0.73 \\
\hline The mean core length $(\mathrm{mm})$ & & & \\
\hline PSA: Prostate spesific antigen & &
\end{tabular}

Table 3. Comparison of the data according to Gleason grade
\begin{tabular}{|l|l|l|l|l|}
\hline & Gleason grade $\leq \mathbf{6}$ & Gleason grade $\mathbf{7}$ & Gleason grade $\geq \mathbf{7}$ & $\mathbf{p}$ value \\
\hline Age (years) & $67(49-81)$ & $70(56-81)$ & $69(53-80)$ & 0.18 \\
\hline Prostate volume (cc) & $42(18-110)$ & $41(22-78)$ & $50(25-115)$ & 0.30 \\
\hline The mean core length $(\mathrm{mm})$ & $10.42(6.08-17.3)$ & $10.91(4.50-15.25)$ & $12.33(7.92-18.42)$ & 0.12 \\
\hline The mean core length taken per cc of prostate $(\mathrm{cc} / \mathrm{mm})$ & $2.83(1.14-6.43)$ & $3.68(0.93-7.64)$ & $3.35(1.35-7.60)$ & 0.059 \\
\hline PSA (ng/mL) & $7.60(3.63-100)$ & $21(4.64-591)$ & $39.96(8.2-236)$ & 0.004 \\
\hline PSA: Prostate sepesific antigen & & & \\
\hline
\end{tabular}


$17 \%$ and mortality risk is only $3 \%$. For this reason, it is questioned if we really need to diagnose each and every case of prostate cancer $(15,16)$.

By lowering the cut-off value of PSA, more tumors can be diagnosed at an early stage and can be treated before reaching a palpable level by rectal examination. Nevertheless many more clinically insignificant cancers are also identified, hence unnecessary treatments are applied. In our study, prostate cancer was detected in three of twenty seven patients who displayed PSA values of 2.5-4 $\mathrm{ng} / \mathrm{dL}$ and all the three were clinically insignificant cancer cases. The average core length and previously defined core length per $\mathrm{cc}$ of the prostate volume were found to be similar in the three groups, which may suggest that the other factors influencing detection rates (e.g. length and number of cores) were minimalized.

In order to tackle the uncertainties in the diagnosis and treatment of prostate cancer, novel diagnostic and screening methods should be developed that would ignore clinically insignificant prostate cancers but would never miss out clinically significant cases. For this purpose, increased use of multiparametric magnetic resonance imaging (mp-MRI) and magnetic resonance imaging (MRI)-guided prostate biopsy looks promising and encouraging. In patients with one or more negative prostate biopsy results, MRI-guided prostate biopsy performed in suspicious areas detected by three Tesla mp-MRI was shown to detect prostate cancer at a rate of $41 \%$ and, consequently, $87 \%$ of these cancers were identified as clinically significant cancers (17).

Pepe et al. (18) performed saturation biopsy in 100 patients in whom prostate cancer was not detected in the first biopsy, but PSA remained high and continued to increase during the follow-up. Before biopsy, three Tesla mp-MRI was performed in all patients. Additional biopsies were taken from suspicious areas in patients with suspected tumors identified on mp-MRI. Prostate cancer was diagnosed in a total of 37 patients. Mp-MRI targeted biopsies diagnosed cancer in 29 patients. The remaining eight patients with undetectable tumors by $\mathrm{mp}-\mathrm{MRI}$ targeted biopsies were found to be clinically insignificant cases. The authors concluded that mp-MRI can provide a significant improvement in the diagnosis of prostate cancer and, consequently, those that remain undetected in this way are clinically insignificant cancers (18). The European Association of Urology Guidelines suggest using additional diagnostic options, such as risk calculator, Prostate Health Index and 4K score, in asymptomatic men having PSA values between $2.0 \mathrm{ng} / \mathrm{mL}$ and $10 \mathrm{ng} / \mathrm{mL}$.

Limitations of our study can be listed as being a retrospective study and limited number of patients which is insufficient to determine a definite PSA threshold.

\section{Conclusion}

Prostate cancer was not detected in our study in any patient with a PSA value below $3.6 \mathrm{ng} / \mathrm{mL}$. Lowering PSA cut-off value to $3.6 \mathrm{ng} / \mathrm{mL}$ may prevent unnecessary prostate biopsies. In order to get through the difficulties regarding the uncertainties in the diagnosis and treatment of prostate cancer, we should develop novel diagnostic and screening methods that could disregard clinically insignificant prostate cancers but would never skip any clinically significant cases.

\section{Ethics}

Ethics Committee Approval: The study was approved by the Muğla Sıtkı Koçman University Scientific Research and Publication Ethics Committee (Approval number: 5061).

Peer-review: Externally peer-reviewed.

\section{Authorship Contributions}

Surgical and Medical Practices: H.D., H.Ş. Concept: H.D. Design: H.Ş. Data Collection or Processing: H.D., H.Ş. Analysis or Interpretation: H.D., H.Ş. Literature Search: H.D. Writing: H.Ş.

Conflict of Interest: No conflict of interest was declared by the authors.

Financial Disclosure: The authors declared that this study received no financial support.

\section{References}

1. Siegel R, Ma J, Zou Z, Jemal A. Cancer statistics, 2014. CA Cancer J Clin 2014;64:9-29.

2. Schroder FH, Hugosson J, Roobol MJ, et al. Screening and prostate-cancer mortality in a randomized European study. N Engl J Med 2009;360:1320-8.

3. Catalona WJ, Smith DS, Ratliff TL, et al. Measurement of prostate-specific antigen in serum as a screening test for prostate cancer. N Engl J Med 1991;324:1156-61.

4. Schröder FH, van der Cruijsen-Koeter I, de Koning HJ, Vis AN, Hoedemaeker RF, Kranse R. Prostate cancer detection at low prostate specific antigen. J Urol 2000;163:806-12.

5. Catalona WJ, Smith DS, Ornstein DK. Prostate cancer detection in men with serum PSA concentrations of 2.6 to $4.0 \mathrm{ng} / \mathrm{mL}$ and benign prostate examination. Enhancement of specificity with free PSA measurements. JAMA 1997;277:1452-5.

6. Deliktas H, Sahin H, Cetinkaya M, Dere Y, Erdogan O, Baldemir E. Does core length taken per cc of prostate volume in prostate biopsy affect the diagnosis of prostate cancer? Clin Genitourin Cancer 2016;14:e387-91.

7. Obek C, Ozkan B, Tunc B, Can G, Yalcin V, Solok V. Comparison of 3 different methods of anesthesia before transrectal prostate biopsy: a prospective randomized trial. J Urol 2004;172:502-5. 
8. Stephenson AJ, Jones JS, Hernandez AV, Ciezki JP, Gong MC, Klein EA. Analysis of T1c prostate cancers treated at very low prostate-specific antigen levels. Eur Urol. 2009;55:610-6.

9. Heidenreich A, Bellmunt J, Bolla $M$, et al. [EAU guidelines on prostate cancer. Part I: screening, diagnosis, and treatment of clinically localised disease]. Actas Urol Esp 2011;35:501-14.

10. Carter HB, Pearson JD. Prostate-specific antigen testing for early diagnosis of prostate cancer: formulation of guidelines. Urology 1999;54:780-6.

11. Thompson IM, Pauler DK, Goodman PJ, et al. Prevalence of prostate cancer among men with a prostate-specific antigen level < or =4.0 ng per milliliter. N Engl J Med 2004;350:2239-46.

12. Walsh PC, Partin AW, Epstein Jl. Cancer control and quality of life following anatomical radical retropubic prostatectomy: results at 10 years. J Urol 1994;152:1831-6.

13. Albayrak S, Tanık S, Zengin K, et al. Which prostate spesific antigen level is important? Yeni Üroloji Dergisi 2014;9:38-43.
14. Esen HH, Avunduk MC. Prostat adenokarsinomlarında PSA değerlerinin Gleason Skor ve klinik evre ile ilişkisi. Genel Tıp Dergisi 2007;17:211-5.

15. Merrill RM, Weed DL, Feuer EJ. The lifetime risk of developing prostate cancer in white and black men. Cancer Epidemiol Biomarkers Prev 1997;6:763-8.

16. Jemal A, Tiwari RC, Murray T, et al. Cancer statistics, 2004. CA Cancer J Clin 2004;54:8-29.

17. Hoeks CM, Schouten MG, Bomers JG, et al. Three-Tesa magnetic resonance-guided prostate biopsy in men with increased prostate-specific antigen and repeated, negative, random, systematic, transrectal ultrasound biopsies: detection of clinically significant prostate cancers. Eur Urol 2012;62:902-9.

18. Pepe P, Garufi A, Priolo G, Pennisi M. Can 3-Tesla pelvic phasedarray multiparametric MRI avoid unnecessary repeat prostate biopsy in patients with PSA $<10 \mathrm{ng} / \mathrm{mL}$ ? Clin Genitourin Cancer 2015;13:e27-30. 